\title{
Aborto e ativismo "pró-vida" na política brasileira
}

\author{
Abortion and "pro-life" activism in brazilian policy
}

\section{Ana Carolina de Oliveira Marsicano ${ }^{a}{ }^{\circ}$, Joanildo Albuquerque Burity ${ }^{b} \odot$}

Resumo Neste artigo, buscamos analisar a atuação de grupos políticos conservadores e antidireitos a partir das proposições legislativas apresentadas na $56^{\mathrm{a}}$ Legislatura (2019-2020) e que versam sobre o aborto e a forma pela qual a interseção entre religião, gênero e sexualidade se manifesta na política contemporânea brasileira. Trata-se de estudo descritivo com abordagem qualiquantitativa das proposições legislativas, considerando a região de origem, religião, gênero e o partido político dos parlamentares que apresentaram as proposições; o eixo temático no campo da discussão dos direitos sexuais e reprodutivos no qual se inserem e em oposição a quais políticas públicas se posicionam. Na primeira seção do artigo abordamos a articulação entre religião, gênero e sexualidade no campo da política, apontando como através de determinada política sexual o discurso conservador do mundo religioso católico e evangélico "pró-vida" se vê reafirmado e reproduzido pelo conservadorismo político que compõe o cenário político contemporâneo no Brasil. Em seguida serão apresentados os resultados obtidos através da sistematização de dadas proposições legislativas, com algumas considerações teórico-metodológicas sobre as fontes utilizadas e a forma de composição dos dados.

Palavras-chave Aborto. Política sexual. Conservadorismo religioso. "Pró-vida".

Abstract This article aims at examining the performance of conservative and antirights political groups and the intersection between religion, gender, and sexuality in contemporary Brazilian politics through an analysis of bills presented during the 56th Legislature (2019-2020) that deal with abortion. This descriptive study applies a mixed-methods approach to legislative procedures, by considering the place of origin, religion, gender, and political party affiliations of parliamentarians who presented those bills. It queries the themes under debate around sexual and reproductive rights and to which public policies they oppose. In the first part of the article, we approach the articulation between religion, gender, and sexuality in the field of

a Doutoranda em Sociologia pela Universidade Federal de Pernambuco (UFPE) pela linha de pesquisa Cultura Política, Identidade Coletivas e Representações Sociais. Bolsista pela Fundação de Amparo à Ciência e Tecnologia do Estado de Pernambuco (FACEPE). E-mail: ana.marsicano@ufpe.br

b Pesquisador titular da Diretoria de Pesquisas Sociais da Fundação Joaquim Nabuco e Professor dos Programas de Pós-graduação em Sociologia e Ciência Política da Universidade Federal de Pernambuco. E-mail: joanildo.burity@fundaj.gov.br 
politics, pointing out how the conservative discourse of Catholic and Evangelical "pro-life" religious activism is reaffirmed and reproduced through a particular sexual policy by the political conservatism that prevails in Brazil's contemporary political scenario. Finally, the results obtained through the study of the proposed bills are presented, coupled with some theoretical and methodological considerations based on the sources chosen and on the form of data composition.

Keywords Abortion. Sexual politics. Religious conservatism. "Pro-life".

\section{INTRODUÇÃO}

O vínculo entre religião e atuação de grupos políticos conservadores e antidireitos ${ }^{1}$ (Morán; Morgan, 2018) em torno da pauta do aborto é de fundamental importância. Os discursos a respeito do aborto nos revelam a forma como a diferença sexual constitui a "infraestrutura" da política sexual, tornando o sexo (reprodução) e a sexualidade (prática/ação) categorias impregnadas de conotações ou implicações políticas. Nesse sentido, ao nos referirmos ao aborto, remetemos a um fato social intrinsecamente ligado a processos sociais, políticos, religiosos e culturais (Rubin, 1996), expressos em concepções, estratégias e práticas que versam sobre corpos, sexualidades dissidentes, direitos e definições da vida desejável (Dides, 2004; VAGgione; Mujica, 2013; Ahumada, 2013). Um dos lugares nos quais esses processos se dão, com efeitos vinculantes para as práticas sociais, é a atividade parlamentar. Nela, somam-se os aspectos de representação grupal, difusão de agendas no debate público e a busca de formalizar em lei determinados "projetos" dos grupos representados ou negociar seu reconhecimento e admissão em iniciativas mais amplas. Desta forma, entendemos que focalizar a produção discursiva - isto é, práticas e produção de sentido inseparavelmente articuladas - na atividade legislativa ajuda a realçar esses aspectos e, assim, evidenciar como se constituem publicamente os vínculos entre religião, gênero e política, com destaque para o campo conservador, que presentemente atravessa referências religiosas e não-religiosas, posicionamentos baseados em abordagens técnicas ou em manifestações de grupos representados, distintas esferas de política pública e variados repertórios de ação intra e extraparlamentar. Através das proposições legislativas da 56 $6^{\mathrm{a}}$ legislatura (2019-2020) na Câmara Federal brasileira, buscamos

1 Ao nos referirmos a "antidireitos" apontamos para a atuação substantiva de atores que exercem uma politização reativa à agenda dos direitos sexuais e reprodutivos das mulheres (Miguel, Biroli, Mariano, 2017; Rosado-Nunes, 2012; Morán; Morgan, 2018). Nesse sentido, o termo assinala uma dada política sexual que restringe o acesso a direitos das mulheres, inviabilizando a autonomia sobre seus corpos e o direitoà realização do aborto legal, seguro e gratuito. 
compreender a forma como o campo religioso conservador e antidireitos se insere na discussão sobre o aborto no campo da política, visando preservar certa tradição religiosa familista-patriarcal. Acreditamos que a intersecção entre aborto e religião é um fenômeno social de grande importância para compreendermos o conservadorismo religioso no Brasil, observando a presença pública das religiões como parte das políticas contemporâneas.

\section{RELIGIÃO, GÊNERO E POLÍTICA}

Desde a década de 90 no Brasil, os movimentos feministas vêm estabelecendo estratégias para inserir no debate público a garantia ao acesso das mulheres ao aborto legal e seguro (CORREA, 2004, p. 4-5). Através de uma intensa campanha pela descriminalização e legalização do aborto, os movimentos feministas conseguiram inserir na agenda pública o debate sobre os direitos sexuais e reprodutivos da mulher, vindo a adquirir uma "dimensão transnacionalista ou internacionalista" (GAGO, 2020) expressa nas diversas manifestações na América Latina em defesa do direito ao aborto legal, seguro e gratuito, como a "maré verde", e o "Ni Una Menos". Como reação e em resposta a essa "reverberação sincrônica" (AGuilar, 2018), observamos um fortalecimento do ativismo em defesa de uma concepção restritiva de sexualidade e enquanto efeito de uma forma de politização reativa de diversos setores religiosos que visam defender um modelo de família e de sexualidade que consideram estar ameaçado por uma nova política sexual.

Essa tendência político-reativa aos avanços na discussão dos direitos sexuais e reprodutivos das mulheres é encontrada em várias partes do mundo, refletindo uma pluralidade de processos cruzados que desencadearam, aos poucos, uma reação conservadora compreendida por muitos (AlmEIDA, 2017; STEFANONI, 2018; Biroli, CAminotTi, 2020) como onda conservadora. Contanto que a entendamos como reação a mudanças efetivas, que não se reduziram às questões de gênero e sexualidade, e que envolveram a própria politização religiosa, concordamos em situar a tendência acima apontada como parte dessa onda conservadora (cf. BURITY, 2018b; 2020a; 2020b). Do ponto de vista da disseminação da tendência que observamos, parece-nos óbvio seu caráter transnacional, manifesto na reiteração de repertórios de ação e na formação de alianças policêntricas, com atuação tanto nas instâncias estatais quanto nos planos da sociedade civil e das práticas cotidianas. Além disso, estes movimentos possuem caráter local e com conformações variáveis, que se articulam de modo flexível, combinando articulações de instituições e grupos religiosos e não-religiosos (entendemos por isso identificações explícitas de pertencimento ou motivação, e não exatamente definições englobantes). Há, ainda, 
um forte engajamento global da Igreja Católica nestes movimentos, tanto através de sua hierarquia como de setores leigos profissionais e, mais recentemente, bases locais mobilizadas. A intervenção se articula em termos que diagnosticam uma ameaça social ou cultural abrangente representada pelos avanços dos movimentos de mulheres e de minorias sexuais e suas pautas. Falando da Igreja Católica, um dos mais proeminentes atores globais dessa reação conservadora, comenta Vaggione:

Para a Igreja Católica, a cultura é também uma arena privilegiada tanto em sua missão evangelizadora como em suas intervenções políticas. (...) Nessa mesma direção, a defesa por parte da Igreja Católica de sua concepção de família e sexualidade surge como a defesa de uma cosmovisão cultural ameaçada. Não está em jogo (somente) uma tradição religiosa, mas a afirmação da Igreja de que a cultura em geral está em risco (VAGGIONE, 2012, p. 63).

A resposta dos setores religiosos aos movimentos feministas nos permite pensar o vínculo entre religião e política, compreendendo quais são as relações de disputa instituídas no campo da política sexual contemporânea e em torno de quais categorias sociais este campo se constitui. A politização da sexualidade nos mostra como há uma forma complexa e múltipla com que a hierarquia católica se articula na América Latina enquanto ator privilegiado nos debates sobre políticas públicas e reformas legais sobre a sexualidade (Htun, 2003; MuJICA, 2007; SGRo; RabBiA; Iosa, 2011). No entanto, há um novo ator, particularmente no contexto americano: os evangélicos. Nos Estados Unidos, a agência evangélica conservadora já experimentou grande institucionalização - de sucesso variável - desde meados dos anos 1970. Na América Latina, o crescimento demográfico e a mobilização política crescente da corrente predominante entre os evangélicos, o pentecostalismo, remontam a meados dos anos 1980, mas a intensificação de sua militância em torno da questão do aborto é mais recente. A liderança da reação conservadora é, no Brasil, claramente partilhada entre pentecostais e católicos, mas não se trata de uma liderança unificada e coesa. A visão que predomina entre os dirigentes pentecostais brasileiros é de que há uma articulação entre corporações internacionais e movimentos sociais de caráter transnacional ameaçando a família, enquanto uma das mais importantes instituições sociais. Segundo Vaggione (2005; 2009; 2012; 2013), esses setores religiosos têm adotado uma retórica secular ao intervir na esfera pública, através de discursos biologistas, jurídicos e socioantropológicos, visando à finalidade política da manutenção do poder e de proteção da ordem moral religiosa "de maioria cristã" sobre a sexualidade e a reprodução. 
No Brasil, o avanço da discussão em torno do aborto configurou a articulação e o fortalecimento de estratégias conservadoras cuja melhor expressão se deu nos debates legislativos nacionais a partir de 2000 (Miguel; Biroli; Mariano, 2017), quando podemos observar a iniciativa de grupos católicos e evangélicos na formulação de propostas legislativas e na formulação de políticas públicas, visando impedir o avanço da pauta dos direitos sexuais e reprodutivos das mulheres. A politização da sexualidade tem permitido que o conservadorismo religioso se articule com organizações não-governamentais antidireitos, que negam qualquer possibilidade de atualização jurídico-política que venha a questionar o paradigma tradicional da sexualidade (VAGGIONE, 2009). Nesse sentido, a infraestrutura da política sexual no Brasil atua enquanto parte de uma articulação transnacional liderada por redes de conservadorismo católico organizado (GonZÁLEZ, 2005), que, através do discurso da defesa da vida e da família, ${ }^{2}$ encobrem uma agenda política de oposição aos direitos sexuais e reprodutivos e se inscrevem em um território cujo controle é constantemente disputado: o corpo da mulher.

No atual embate sobre gênero e sexualidade, lideranças clericais e leigas vêm convocando "mulheres católicas jovens, com instrução superior, que atuam em Organizações Não-Governamentais ligadas à igreja ou integram movimentos como a Renovação Carismática Católica, o Pró-vida e Pró-família etc” (MACHADO, 2018, p. 9). O mesmo se dá no campo evangélico, com grupos mobilizados em redes sociais, candidaturas de mulheres evangélicas a cargos eletivos e ocupação de posições-chave de governo, como no caso da ministra Damares Alves, do governo Bolsonaro, e de outras mulheres evangélicas em funções de assessoria e alta gestão de órgãos públicos. A interseção da política com a religião no debate sobre o aborto nos permite observar a influência de especialistas religiosos (sacerdotes católicos e pastores/as de diversas denominações evangélicas, bem como intelectuais leigos e leigas) com capital religioso convertido em político (ORO, 2002; 2004; MACHADO, 2006), que buscam recrutar ativistas para reafirmação do imaginário conservador religioso sobre o aborto.

Não se trata de simples reprodução das mesmas posições - embora isso também ocorra - nem de adesão incondicional ou agenda única por parte de todas as forças envolvidas nessas mobilizações. É exagerado afirmar um alinhamento

2 Referimo-nos à “vida” e "família” em itálico para fazer alusão às múltiplas formas de atribuir significado a ditos significantes. Nesse sentido, enquanto "vida”, no discurso cristão conservador, significa o feto logo em seguida à concepção, nos discursos médicos e do ativismo de gênero, a palavra se refere a um período posterior do desenvolvimento do embrião humano e se amplia para dar conta da defesa de outras situações de vida (por exemplo, envolvendo crianças e adolescentes). 
integral, uma convergência sem restos, entre aquelas. Antes, a imagem da máquina de ressonância proposta por Deleuze, Guattari e Connolly nos parece captar de que forma as equivalências e aproximações táticas entre as demandas e agendas de setores religiosos e não-religiosos se articulam. Em Deleuze e Guattari, ressonância aparece conectada à segmentaridade circular, de tendência concêntrica nas sociedades modernas, estatalizadas, ao deslocamento de um centro que, no entanto, se mantém relativamente inalterado: "a segmentaridade circular tende a se tornar concêntrica, isto é, ela faz coincidir todas as habitações num só centro, o qual não pára de se deslocar, mas permanece invariante em seus deslocamentos, remetendo a uma máquina de ressonância" (Deleuze; Guattari, 1999, p. 80-81). Ressonância reforça, ainda, a dimensão molar ("endurecida”, institucionalizada, macro), apesar de esta ser sempre fissurada pela dimensão molecular (de massa, flexível, fugidia, individualizada), que vaza e subtrai-se a toda tentativa de controle total, de ressonância sem dissonância (cf. Deleuze; Guattari, 1999, p. 86). Para Connolly, "máquina de ressonância" se aplica à reconstituição de um movimento conservador (originado na Maioria Moral de décadas anteriores) que existiu durante o governo de George W. Bush, e que foi fruto de uma coalizão entre protestantes, pentecostais, católicos, judeus, setores da comunidade de inteligência e defesa e defensores de políticas neoliberais, mas sem que se possa falar numa fusão de "interesses" e "objetivos" entre todos, da mesma forma ou com a mesma intensidade (cf. Connolly, 2008). Dentro dessas linhas e fluxos discursivos ressonantes, podemos observar que, assim como aconteceu no Peru, onde o discurso da vida se tornou indispensável para reproduzir a moral católica (e, acrescentamos, nos últimos anos, também a evangélica conservadora) e naturalizar as hierarquias de gênero (MuJicA, 2007), no Brasil, os movimentos conservadores estreitamente ligados à doutrina e à hierarquia religiosa (católica e evangélica) vêm adotando uma série de discursos e ferramentas como forma de criar uma contraofensiva aos movimentos feministas e por justiça de gênero. Autodenominados "pró-vida", se posicionam de forma antagônica frente àqueles ao qual se referem como "pró-morte” (MoRÁn FAúndes, 2017, p. 19).

Dentro do discurso "pró-vida", os corpos femininos:

resultam indispensáveis não somente para a reprodução-da-vida (como matéria biológica) mas também para a reprodução-da-vida (como tecnologia de dominação patriarcal). A partir disso, a vida feminina passou a ser considerada como administrável e seus corpos como campo de subordinação(SEvilla; Nicoli, 2020, p. 112). 
Integra, assim, à tática do movimento "pró-vida”, recorrer à origem etimológica de certas noções como vida, morte e sexo, reconstruídas em termos que elidem variações ou oscilações de sentido, ou apresentar fundamentações teóricas sustentadas pela própria instituição religiosa (como os discursos da "vida-na-concepção" e da "ideologia de gênero"). Essa forma de "secularismo estratégico" (VAGGIONE, 2010) é expresso nos discursos religiosos que recorrem a uma retórica secular científica e jurídica, apresentando-os enquanto verdade objetiva e neutra. Em nossa terminologia, mais do que uma estratégia particular, esses procedimentos se inscrevem na configuração política mais ampla da religião pública.

É importante ressaltar que o processo de "desprivatização da religião"3 (CASANOva, 1994) representa tanto a emergência de atores religiosos nos espaços públicos da política visando defender uma ordem tradicional, intervindo publicamente enquanto atores da sociedade civil que buscam integrar os principais debates democráticos, quanto uma forma de responder a essa ameaça à família tradicional cristã e se posicionar diante de uma guerra "espiritual" que é, a um só tempo, local e global (MACHADO, 2013, p. 52). Esta situação caracteriza boa parte das mobilizações da religião no cenário contemporâneo, o que não apenas a torna um ator, como abre o discurso religioso à contestação interpretativa e prática por parte de aliados e adversários.

A articulação entre setores religiosos e da sociedade é denominada "ecumenismo civil” por Morán Faúndes (2015), consistindo em aliança nas quais as religiões deixam de lado as tensões entre suas identidades religiosas particulares para se articularem em torno de uma agenda compartilhada (MORÁN FAÚNDES, 2015, p. 7). Nesse sentido, essa multiplicidade religiosa tem se organizado em torno de um objetivo comum (mas limitado, ou antes, inscrito de forma policêntrica numa estratégia que vai além dele, "convergindo" em seus efeitos numa nova formação hegemônica, a da reação conservadora, transnacionalmente disseminada como onda conservadora), capaz de dotar seus atores de maior força política para debater as políticas sexuais tanto no espaço da política institucional estatal, quanto na esfera pública, na chamada sociedade civil. É importante ressaltar que ao colocar em evidência a emergência pública das religiões, surge a necessidade de "perce-

3 Ao trabalhar as fronteiras entre laicidade, secularidade e a relação entre religião e política, essa "desprivatização" - questionável em muitos contextos nos quais jamais houve ou foi plenamente sucedida a fórmula liberal da separação religião-estado e da subjetivação e privatização da consciência e prática religiosas - nos mostra haver um deslocamento das fronteiras de produção de discurso a partir da presença, manifestação e publicização das religiões ao atuarem diretamente na esfera pública. Sobre a tese da "desprivatização" ver Casanova (1994, p. 5-10, 58, 65, 211, 224; 2008, p. 101-19; 2010, p. 19-36). 
bermos a composição dessa cena, seus atores, scripts e cenários, tanto quanto as tecnologias que a capturam e difundem" (Burity, 2015, p. 90). Ao analisar as condições para que a fronteira da esfera privada venha adentrar a esfera pública, irrompendo na mobilização política de grupos religiosos, Burity aponta se tratar de uma agência reativa, que provoca "uma tentativa de reasserção de vozes religiosas" e de uma agência construtiva, de atores religiosos que estariam "refazendo suas posições mesmo quando reafirmam tradições antigas” (BURITY, 2015, p. 93-94).

Esses grupos, na medida em que reagem e constroem, negociam suas posições no campo da política e refazem as fronteiras entre o político e o religioso, alterando a cartografia política ao se inserirem de forma articulada ao contexto, ou seja, de forma relacional e agonística/antagônica ${ }^{4}$. A partir da conjuntura pós-eleições de 2014, observou-se uma maior projeção desses atores no legislativo e no executivo. Dentro de uma onda conservadora na religião, na política e nas relações interpessoais, atores religiosos aparecem como importantes protagonistas na produção desse conservadorismo crescente e reativo ao avanço nas demandas minoritárias no pós-2003 (Burity, 2018, p. 28). Nesse sentido, o que observamos foi uma reação conservadora religiosa a temas e a uma formação hegemônica prévia, forjada nos governos petistas (2003-2016) e que fez confluir setores evangélico-pentecostais (altamente bem-sucedidos na sua estratégia de construção de uma representação política), católicos e seculares (direita política, militar e neoliberal) em torno do tema dos direitos sexuais e reprodutivos das mulheres.

\section{O ABORTO NO BRASIL}

Em 2018 ocorreu um debate público em decorrência da ADI 55815, contando com a presença de atores que representavam diferentes segmentos sociais e com argumentações a favor e contra a descriminalização do aborto até a $12^{\mathrm{a}}$ semana de gestação. Movimentos sociais, organizações não-governamentais, defensorias públicas, entidades de classe da área da saúde e especialistas/pesquisadores no tema produziram uma politização da agenda dos direitos sexuais e reprodutivos

4 A relacionalidade incide sobre tudo o que se refere à formação da identidade, crenças e agendas desses atores. As condições concretas de emergência da politização religiosa e os discursos mobilizados para anunciá-la, justificá-la e pô-la em cena definem se se tratará de disputas dentro de um referencial macro, valorativo e/ou institucional, que reconhecem (agonismo - luta dentro de regras compartilhadas, mas com conteúdos disputados e em torno de "temas" disputados) ou se se tratará de combates ferrenhos onde tudo o que diz respeito ao outro precisa estar em questão, onde o jogo proposto, embora, na prática, nem sempre consumado, é de soma zero (antagonismo - configuração amigo/inimigo, nós/eles(as), dicotomização do social).

5 Em virtude da epidemia do Zika vírus, em agosto de 2016, foi protocolada no Supremo Tribunal Federal (STF) uma Ação Direta de Inconstitucionalidade (ADI 5581) para garantir a possibilidade de interrupção da gestação em casos de infecção. 
(BIROLI, 2018). Em oposição, grupos que se apresentavam publicamente como "pró-vida" e representantes de uma "cultura de vida”, lançaram mão de argumentos como o da valorização da vida intrauterina. Machado (2013), em pesquisa realizada com cinquenta e oito lideranças pentecostais, observou a assimetria de gênero presente na maioria das igrejas pentecostais e renovadas, embora as entrevistadas possuíssem grande projeção dentro do segmento pentecostal (p. 51). Uma das lideranças entrevistadas foi Damares Alves, pastora e advogada, que chegou a atuar como assessora parlamentar na Câmara Federal, como consultora jurídica da Frente Parlamentar Evangélica e que ocupa o posto de ministra da Mulher, da Família e dos Direitos Humanos desde o início do governo Bolsonaro. Sua equipe, além de ser integrada por mulheres que já se posicionaram publicamente contra o aborto, inclusive na hipótese de estupro (MENDONÇA, 2020), vem estabelecendo articulações com grupos, entidades e organizações que representam o ativismo “pró-vida”. Angela Vidal, que ocupa a pasta de Secretária Nacional da Família, é filha do jurista integrante da Opus Dei e porta-voz da política conservadora religiosa, Ives Gandra. Representativos de uma forma de articulação jurídico-religiosa na política, integram o Conselho do Instituto Brasileiro de Direito e Religião ${ }^{6}$, o qual contesta a laicidade e a secularização da política.

A articulação jurídico-religiosa na política brasileira pode ser observada pela presença de representantes do Instituto Brasileiro de Direito e Religião e da Associação Nacional de Juristas Evangélicos (Anajure)7 em pastas estratégicas para as políticas dirigidas às mulheres e também pela presença de diversos deputados federais evangélicos e católicos que possuem formação jurídica e atuam incisivamente na defesa de pautas conservadoras, dentre elas a agenda "pró-vida". Essa forma de judicialização reativa aos avanços da política feminista, ao acionar o direito como estratégia central para defender a política sexual conservadora e religiosa, se manifesta de duas formas, segundo Monte e Vaggione:

Em primeiro lugar, apresentamos a judicialização conservadora destinada a impossibilitar o acesso das mulheres ao aborto na hipótese de aborto não criminalizado. E em segundo lugar, analizamos a judicialização conservadora destinada a impugnar os protocolos de atenção de abortos não criminalizados que garantam o acesso das mulheres grávidas ao aborto não criminalizado (MoNTE;

VAGGIONE, 2019, p. 115).

6 Para maiores informações, consultar: https://www.ibdr.org.br/. Acesso em 12/05/2021.

7 Note-se que a Anajure teve como uma de suas fundadoras Damares Alves. Para maiores informações, consultar: https://anajure.org.br/. Acesso em 12/05/2021. 
A utilização de argumentos e estratégias legais no âmbito da política para fins de proteção aos valores cristãos na sociedade impõe o desafio analítico de compreender o conteúdo normativo, simbólico e político dessas propostas. De um lado, tal utilização exibe a reconfiguração discursiva que expressa e operacionaliza em parte a reação conservadora. Em sua obra Gênero, Neoconservadorismo e Democracia (2020), Biroli, Machado e Vaggione apontam como uma das matrizes de ação do conservadorismo religioso a acentuada "juridificação" da moralidade.

O conceito de juridificação é apresentado no capítulo escrito por Vaggione (2020) para tratar do movimento de restauração por meio do direito, pelo qual atores religiosos e seculares defendem uma ordem moral específica. Segundo o autor, o paradigma dos direitos sexuais e reprodutivos "leva o processo de secularização do direito a um novo limiar" (VAGGIONE, 2020, p. 43), caracterizado por uma desarticulação entre direito secular e moral católica. Ultrapassando a dicotomização entre religioso e secular, a secularização "estratégica” do direito envolve tanto uma dimensão funcional, ao posicionar o Estado como regulador da sexualidade e da reprodução, como também material, no que tange ao conteúdo dessa regulação. Para que possamos analisar a forma como a dimensão material "camufla" conteúdos morais e religiosos e a forma como os processa e instrumentaliza por meio do discurso sexual, torna-se importante "romper com o mito do direito secular (e suas pretensões de objetividade e universalidade) por meio da compreensão das intrincadas imbricações e relações com o religioso que se des/ rearticulam de formas móveis" (VAGGIONE, 2020, p. 46).

A Igreja Católica moderna, ao reivindicar seu direito de ser um ator público, recorre ao uso de uma maquinaria legal para fins de promover a juridificação da moral católica através da atuação de políticos, advogados e juristas cristãos que encontram em sua identificação religiosa (católica ou evangélica) uma motivação para sua atuação política. A defesa de princípios morais católicos faz com que surjam novos atores e novas alianças entre católicos e evangélicos que negociam, afirmam-se, reveem, conquistam espaços, são reposicionados e contidos, agindo não somente como uma agência religiosa reativa e proativa, mas também de forma articulada ao contexto, ou seja, de maneira relacional (BuRITy, 2015, p. 94).

\section{METODOLOGIA}

Este artigo é um estudo exploratório, descritivo, com abordagem qualiquantitativa, produzido a partir do banco de dados online da Câmara dos Deputados, consultado no período de 2019-2020. Para a captura das proposições legislativas apresentadas pelos/as parlamentares, privilegiamos as propostas nas quais o 
tema do aborto possuía centralidade. Após serem analisadas, tais proposições legislativas antidireitos foram classificadas, com base no próprio teor documental, em três eixos temáticos: punitivismo (punição, castração química, aumento de penas, mudança nos critérios de progressão de regime e etc.), status do nascituro (proteção e disputa pela definição do início da vida) e direitos sexuais e reprodutivos (obstacularizando o debate sobre o aborto e os métodos de prevenção a gravidez). Após seleção das proposições legislativas, foi realizada a triagem inicial, baseada nas ementas, com exclusão de todas aquelas não relacionadas aos eixos temáticos criados para classificá-los. Buscas foram feitas a partir das palavras "aborto", "direitos sexuais e reprodutivos", "nascituro" e "ideologia de gênero", tendo em vista as diferentes formas com que os/as proponentes se referem ao tema. Durante a pesquisa, percebemos que as frentes parlamentares e sua composição são uma importante via para observarmos a posição que os atores ocupam no campo da política e o grau de comprometimento com o ativismo "pró-vida" e antidireitos. Selecionamos seis frentes parlamentares para fazer uma análise preliminar, apresentada na próxima seção.

\section{CÂMARA DOS DEPUTADOS}

Nas eleições de 2019, o Partido Social Liberal (PSL) elegeu a segunda maior bancada da Câmara dos Deputados, tendo sido eleitas, dentre os 513 deputados, 77 mulheres. Da $56^{\text {a }}$ legislatura, consideramos seis Frentes Parlamentares, a fim de estabelecer a posição que esses atores ocupam no campo da discussão sobre o aborto: a Frente Parlamentar Mista Contra o Aborto e em Defesa da Vida; a Frente Parlamentar Mista Católica Apostólica Romana; a Frente Parlamentar em Defesa da Vida e da Família; a Frente Parlamentar em Defesa do Homeschooling; a Frente Parlamentar com Participação Popular Feminista e Antirracista; e a Frente Parlamentar em Defesa dos Direitos da Mulher. A Frente Parlamentar Mista Contra o Aborto e em Defesa da Vida conta com a participação de 194 deputados e 12 senadores, sendo composta por 27 mulheres (13, 10\%) e 179 homens $(86,89 \%)$. A Frente Parlamentar Mista Católica Apostólica Romana conta com a participação de 207 deputados e 9 senadores, sendo composta por 17 mulheres (7, 87\%) e 199 homens (92, 12\%). A Frente Parlamentar em Defesa da Vida e da Família conta com a participação de 219 deputados, sendo composta por 22 mulheres (10, 04\%) e 197 homens (89, 95\%). A Frente Parlamentar em Defesa do Homeschooling conta com a participação de 240 deputados, dentre eles 25 mulheres (10, 41\%) e 215 homens (89, 58\%). A Frente Parlamentar com Participação Popular Feminista e Antirracista conta com a participação de 212 deputados, dentre eles 37 mulheres 
(17, 45\%) e 175 homens (82, 54\%). Por último, a Frente Parlamentar em Defesa dos Direitos da Mulher, conta com a participação de 207 deputados, dentre eles 166 homens (80, 19\%) e 41 mulheres (19, 80\%).

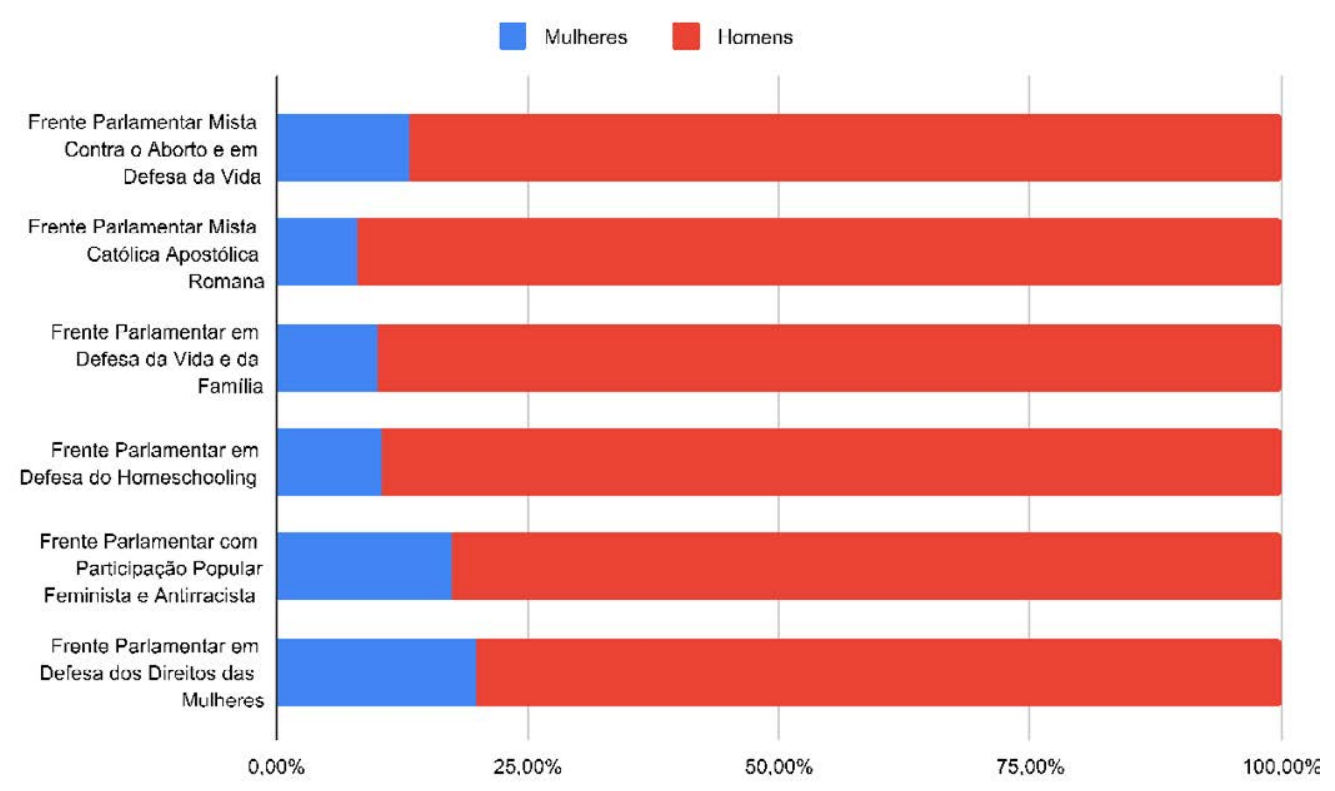

Gráfico 1. Proporção de Homens e Mulheres nas Frentes Parlamentares da $56^{\text {a }}$ Legislatura. Fonte: Elaboração própria.

Das 207 pessoas que integram a Frente Parlamentar Católica, 101 deputados (48, 79\%) também integram a Frente Parlamentar contra o Aborto, dentre eles 11 mulheres $(10,89 \%)$ e 90 homens $(89,10 \%)$. Importante observar que não existe unanimidade interna na Frente Parlamentar Católica: alguns deputados integram a Frente Parlamentar contra o Aborto, enquanto outros integram a Frente Parlamentar Feminista e Antirracista. Nesse sentido, criamos uma espécie de escore para avaliar o grau de ativismo e posicionamento desses atores no que tange à discussão sobre o aborto. Incluídos/as no escore 1 estão aqueles/as que integram a Frente Parlamentar Católica simultaneamente à participação na Frente Parlamentar Feminista e Antirracista e/ou na Frente Parlamentar dos Direitos da Mulher. No escore 2, estão aqueles/as que integram somente a Frente Parlamentar Católica, ou também integram a Frente Parlamentar em Defesa da Família, junto ou não à participação na Frente Parlamentar em Defesa do Homeschooling, simultaneamente à participação na Frente Parlamentar Feminista e Antirracista e/ou na Frente Parlamentar dos Direitos da Mulher. No escore 3, incluímos aqueles/as que integram a Frente Parlamentar Católica simultaneamente à participação na Frente Parlamentar em Defesa da Família ou na Frente Parlamentar em Defesa do Homeschooling. No escore 4 estão aqueles/as que integram a Frente Parlamentar 
Católica, a Frente Parlamentar em Defesa da Família e a Frente Parlamentar em Defesa do Homeschooling; e, por último, está o escore 5, que descreve aqueles que integram a Frente Parlamentar Católica, a Frente Parlamentar contra o Aborto, a Frente Parlamentar em Defesa da Família, e a Frente Parlamentar em Defesa do Homeschooling, integrando ou não a Frente Parlamentar Feminista e Antirracista e/ou a Frente Parlamentar dos Direitos da Mulher. Verificamos dessa forma que 52, 2\% (escores 1, 2, 3 e 4) dos deputados que integram a Frente Parlamentar Católica não participam da Frente Parlamentar contra o Aborto, enquanto 47, 8\% (escore 5) a integram.

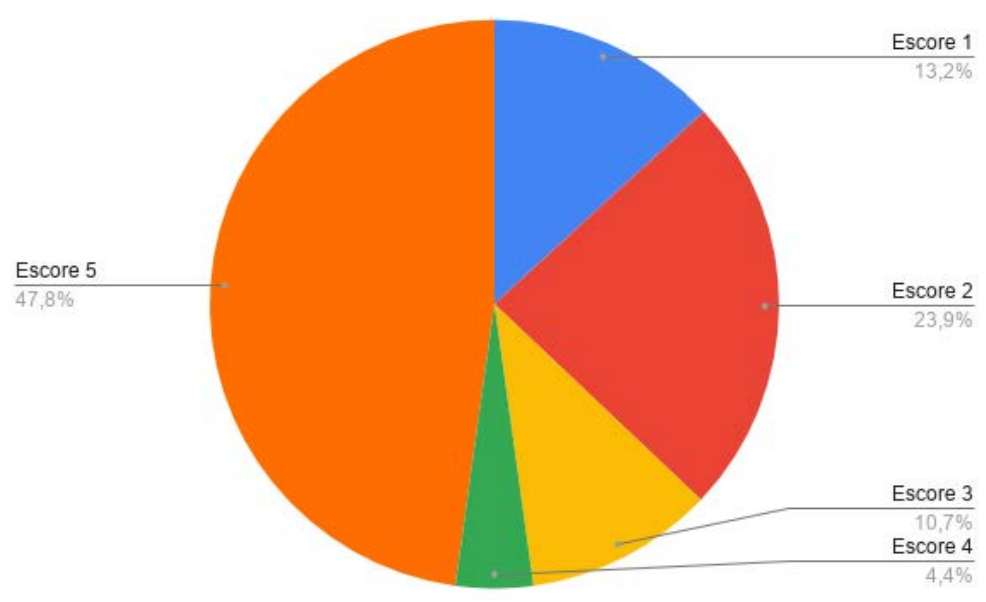

Gráfico 2. Escore de ativismo antidireitos daqueles que integram a Frente Parlamentar Católica (FC). Fonte: Elaboração própria.

É importante ressaltar que essa tentativa de sistematização dos dados em escores, visando avaliar preliminarmente o grau de comprometimento dos deputados com o ativismo "pró-vida" (antidireitos), requer um maior aprofundamento em relação a suas proposições, discursos e articulações. Nesse sentido, essa sistematização visa explicitar inicialmente a existência de uma heterogeneidade interna no âmbito da Frente Parlamentar Católica (FC), abrindo um campo de observação para que possamos analisar, por exemplo, a diferença entre os discursos no âmbito da Frente Parlamentar Contra o Aborto (FA) e da Frente Parlamentar em Defesa da Família (FF), e a existência ou não de tensões internas ao campo religioso católico e a forma como se articulam (ou não) aos interesses dos evangélicos conservadores na política.

\section{PROPOSTAS LEGISLATIVAS NA 56 ${ }^{\mathrm{a}}$ LEGISLATURA (2019-2020)}

Em seu trabalho Neoconservadorismo de periferia: articulação familista, punitiva e neoliberal na Câmara dos Deputados, Lacerda (2018) aponta uma 
progressiva queda no ativismo contra o aborto no período entre 2002-2016, havendo uma substituição do ativismo contra o aborto por uma ação pró-família patriarcal com o combate às demandas LGBT e ao próprio conceito de gênero (p. 77). No entanto, podemos observar, a partir de 2019, um crescimento nas proposições legislativas referentes ao aborto, contabilizando 102 proposições, frente às 44 proposições apresentadas no ano de 2018. Estima-se que, até setembro de 2020, houve uma crescente de 83\% nas proposições legislativas (22 proposições) em comparação ao mesmo período no ano anterior (12 proposições). É possível verificar esse aumento a partir do gráfico abaixo. No ano de 2019, os principais debates sobre o aborto giraram em torno da definição do marco no qual se dá o início da vida, os limites da liberdade reprodutiva e sexual e a penalização ou não de sua prática. As proposições legislativas sobre o aborto possuem forte co-relação ao contexto social no qual são apresentadas, havendo uma inconstância no volume de proposições, a refletir certo grau de correspondência ou reatividade a iniciativas políticas e sociais no campo dos direitos sexuais e reprodutivos, ou enquanto resposta a determinado evento que venha a mobilizar a opinião pública. Nesse sentido, podemos observar que não existe uma regularidade no volume de proposições legislativas apresentadas ao longo dos anos de 2002-2020, mas sim uma espécie de variabilidade contingencial.

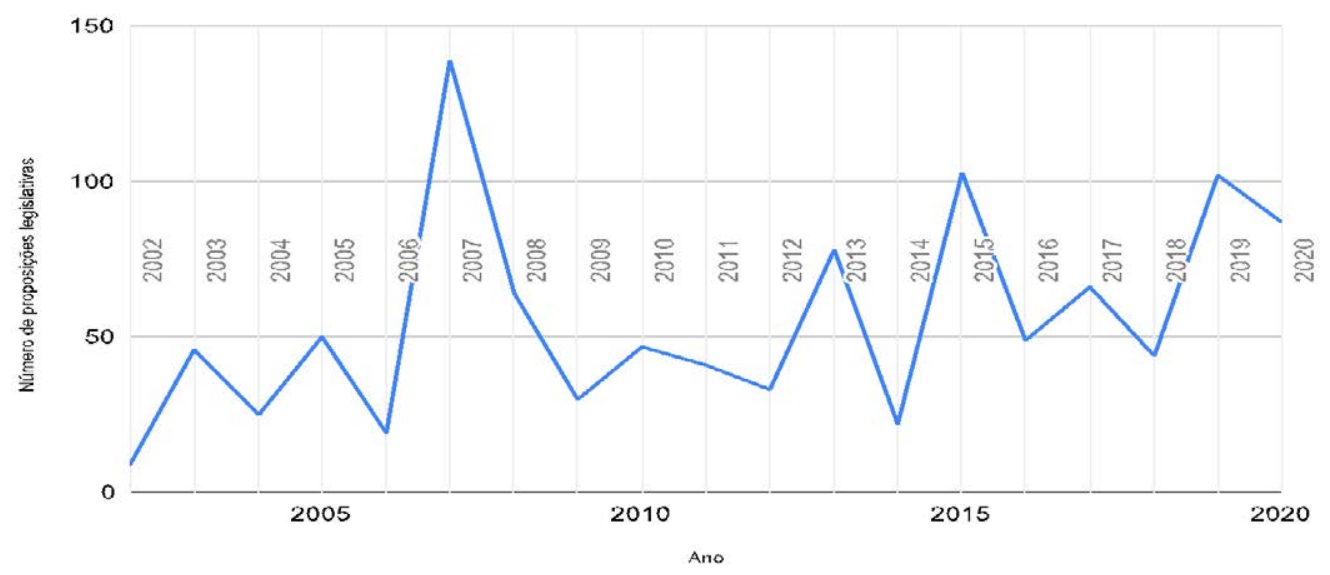

Gráfico 3. Proposições legislativas na Câmara dos Deputados (2002-2020). Fonte: Elaboração própria.

Das proposições antidireitos em 2019 e 2020, 79, 2\% foram apresentadas por homens e 20, $8 \%$ por mulheres, sendo 47, 9\% de deputados do Sudeste, 18, $8 \%$ do Sul, 14, 6\% do Nordeste, 10, 4\% do Centro-Oeste e 8, 3\% do Norte. Em relação aos partidos daqueles/as que apresentaram essas proposições, temos a dianteira do Partido Social Liberal - PSL (27, 4\%), Partido Liberal - PL (19, 4\%) e Republi- 
canos (11, 5\%). Quanto à religião dos proponentes, grande parte se divide entre evangélicos $(39,6 \%)$, cristãos $(22,6 \%$, que podem incluir católicos, evangélicos, espíritas e mesmo pessoas sem vínculo religioso claro) e católicos (20, 8\%) - um total de $83 \%$ de cristãos/ãs. Quanto à profissão, mais da metade $(67,5 \%)$ se divide entre policial/delegado/militar (26\%), advogado (12\%), pastor/bispo/teólogo (18\%) e policiais ou delegados (11, 5\%). Dos 53 deputados que apresentaram proposições dentro de 1 dos 3 eixos temáticos definidos na metodologia, 23 correspondem ao escore 5 (o mais alto no grau de ativismo antidireitos) e 19 integram a Frente Parlamentar contra o Aborto.

As proposições dos deputados que exercem oposição ao ativismo antidireitos trataram, sobretudo, de defender os direitos sexuais e reprodutivos, oferecendo resistência às tentativas de criminalização do aborto em qualquer hipótese. Frequentemente, essas pessoas recorrem a terminologias com que os setores conservadores se recusam a dialogar, dentre elas "direitos sexuais e reprodutivos", “aborto legal e seguro" e "interrupção voluntária da gravidez". Em 2020 foram apresentadas cinco proposições legislativas como reação à Nota Técnica ${ }^{0} 16 / 2020$ sobre "Acesso à saúde sexual e reprodutiva no contexto da pandemia da COVID19”, elaborada pelo Ministério da Saúde. Para fins de garantir acesso integral à saúde sexual e reprodutiva, consideraram-se serviços essenciais e ininterruptos os serviços de atenção à violência sexual; o acesso à contracepção de emergência; o direito de adolescentes e mulheres à Saúde Sexual e Saúde Reprodutiva (SSSR) e abortamento seguro para os casos previstos em Lei; prevenção e tratamento de infecções sexualmente transmissíveis, incluindo diagnóstico e tratamento para HIV/AIDS; e, sobretudo, inclusão da contracepção como uma necessidade essencial. Como reação a essa nota, Chris Tonietto (PSL-RJ) apresentou 3 das 5 proposições legislativas, dentre elas o Projeto de Lei 250/2020, que afirma ser "mero eufemismo para aborto" tanto a norma técnica como o uso de termos como "planejamento familiar" e "contracepção de emergência". Como justificativa para sua fundamentação, recorreu ao direito, alegando a inviolabilidade da vida e se referindo ao aborto como "assassinato intrauterino":

Não obstante a flagrante ilegalidade da norma que se visa sustar, já que o direito à vida é tido por nosso ordenamento jurídico como inviolável, prever a possibilidade de realizar o assassinato intrauterino no sistema público de saúde sem considerar o caos em que se encontra o respectivo setor, que há décadas está sucateado, e que existe um número expressivo de pacientes cujas vidas dependem de intervenções cirúrgicas constantemente adiadas e, até mesmo, da oferta de 
medicamentos que costumeiramente estão em falta - sobretudo em tempos de pandemia -, é no mínimo desrespeitoso! É praticamente como escolher a morte (dos bebês indefesos) em vez da vida (de um sem número de pacientes que necessitam de atendimento) (Brasil, CÂmara dos Deputados, 2020a).

O Projeto de Decreto Legislativo de Sustação de Atos Normativos do Poder Executivo (PDL) 251/2020 apresentada por Dr. Jaziel (PL-CE) pede também que os efeitos da norma técnica sejam sustados por acreditar que suas orientações destoam do "Direito à Vida desde a sua concepção". Segundo o deputado, as regras do Ministério de Saúde sobre aborto legal foram criadas pelas gestões petistas, abrindo brechas para que sejam realizadas em gestações que não decorreram de estupro, contribuindo para a impunidade do estuprador, já que não exige o boletim de ocorrência. Afirma ainda ficar clara a "interferência de entidade internacional e ideologicamente engajada na promoção do aborto", comprometida com a "política antinatalista de "direitos sexuais e reprodutivos". O Projeto de Decreto Legislativo de Sustação de Atos Normativos do Poder Executivo (PDL) 271/2020, apresentado pelo deputado Filipe Barros (PSL/PR), pediu que fossem sustadas não somente a Nota Técnica 16/2020, mas também todas as versões posteriores, ampliadas e autorizadas das Normas Técnicas intituladas "Prevenção e tratamento dos agravos resultantes da violência sexual contra mulheres e adolescentes” (1998) e sobre "Atenção Humanizada ao Abortamento" (2005). Para tanto, recorre ao argumento da "rejeição do povo brasileiro à legalização do aborto", dizendo que essas normas e notas técnicas são uma forma de "burlar a vontade popular expressa pelas decisões do Congresso e, assim, facilitar a prática do crime de aborto no Brasil”. Afirma ainda que:

Por meio das citadas normas técnicas, há anos, o governo brasileiro tem caído numa constrangedora contradição já que, por um lado, defende a ordem e o império da lei, mas por outro, usa o dinheiro do contribuinte por meio do Sistema Único de Saúde para financiar a criminosa eliminação de bebês em gestação. Isso ocorre porque deturpa-se de forma grosseira a expressão "não punível" para o aborto em caso de estupro, como se a ausência de pena para o criminoso gerasse obrigação ao estado de assassinar nascituros, com o aval da mãe (BRASIL, CÂmara dos Deputados, 2020b).

Como reação ao pedido de revogação da Nota Técnica 16/2020 foram apresentados os Requerimentos 1469/2020 e 600/2020, propostos por deputados do PSOL 
que integram as Frentes Parlamentares Feminista e Antirracista e/ou a Frente Parlamentar pelos Direitos da Mulher. A estratégia do ativismo político antidireitos pode ser melhor compreendida através da leitura da Proposta de Lei 2893/2019 apresentada por Chris Tonietto (PSL-RJ) junto de Filipe Barros (PSL-PR). Segundo os deputados, a hipótese legal na qual o aborto é permitido não confere a mulher o direito de realização do aborto, mas somente a não aplicação da punição caso esse venha a ser realizado. Conforme consta na PL, para os deputados,

No caso da vida intrauterina, o bebê não pode ser sentenciado à morte sem culpa e sem julgamento. Ao condenar sumariamente o bebê à morte, a pena não apenas passa do pai para o filho, mas é aumentada: de pena de reclusão para pena de morte! O autor do estupro ao menos poupou a vida da mulher - senão ela não estaria grávida. Pergunta que não quer calar: é justo que se faça com a criança o que nem sequer o agressor ousou fazer com a mãe: matá-la? Não se diga que em tal caso a escolha cabe “à mulher”. Não só porque ninguém - homem ou mulher - tem o direito de decidir sobre a vida e a morte de outrem, mas ainda porque aproximadamente cinquenta por cento das crianças concebidas (em um estupro ou não) são meninas; tão mulheres como suas próprias mães. Se uma mulher deve decidir, pergunto eu: qual delas? A grande ou a pequena? A de dentro ou a de fora? A que sobreviveu à violência ou aquela ameaçada de morte no ambiente intrauterino? (BRASIL, CÂMARA dos DEPUTADOs, 2019).

A utilização de termos como "assassinato intrauterino" ou "causa abortista" reforça o argumento de que a política de direitos sexuais e reprodutivos atua como política de morte e de negação da vida, ao passo que esses/as parlamentares representariam a política "pró-vida", sobretudo na defesa vicária do "nascituro". Em agosto de 2020 foi midiatizado o caso da menina de 10 anos estuprada pelo tio e que teve seu direito de realização do aborto negado no Espírito Santo, mesmo mediante autorização judicial (REzENDE, 2020). Ao se realizar o procedimento na cidade de Recife, um grupo de ativistas religiosos "pró-vida” (alguns ocupando cargos políticos, outros médicos/as e enfermeiros/as, e outros ativistas) tentou intimidar a criança, chamando-a de "assassina", censurar sua família e invadir o hospital para impedir a realização do aborto. No interior do hospital, servidores de saúde tentavam obstaculizar o procedimento (CARRARETo, 2020). Note-se que, das 23 proposições legislativas apresentadas em Agosto de 2020, após a realização do referido aborto, 13 apresentavam teor punitivo, prevendo desde o aumento da pena até a "exigência de tratamento complementar de castração química, ou até 
mesmo a cirúrgica, para concessão de progressão da pena restritiva de liberdade" (PL 4233/2020, proposto pelo deputado Eduardo Bolsonaro, PSL-SP).

Quanto à busca pelo reconhecimento dos direitos do "nascituro", foram apresentadas em 2019-2020 proposições requerendo a realização de audiências públicas, visando a debater a necessidade de sua proteção, o reconhecimento legal de sua personalidade e o estabelecimento de uma semana nacional do "nascituro" com o objetivo de "promoção de políticas públicas que visem a melhor proteção ao nascituro", a "propagação de ações que valorizem a vida desde a concepção" e a "[r]ealização de debates, palestras, seminários, congressos e prêmios que abordem a temática da defesa da vida e promovam ações concretas de combate à Cultura da Morte” (Brasil, CÂmara dos Deputados, 2020). A “cultura de morte” mencionada em dada proposição, está associada a uma forma de "mentalidade anticonceptiva" (VAGGIONE, 2012, p. 64) ou de "profilaxia da gravidez" - termo empregado na Lei $\mathrm{n}^{0} 12.845$ de $2013^{8}$ e cuja Proposta de Lei 1977/2020 pede que seja retirada. Esse tipo de ativismo, direcionado a toda forma de contracepção, pode ser visto também na PL 261/2019, apresentada pelo deputado Márcio Labre (PSL/RJ), na qual se propõe a proibição do comércio, propaganda, distribuição e implantação de qualquer dispositivo contraceptivo (dentre eles o dispositivo intrauterino (DIU) e a pílula do dia seguinte) pela Rede Pública de Saúde, por considerar tratarem-se de "micro abortivos".

O ativismo contra todas as formas de contracepção constitui uma forma de "governança reprodutiva" (MORGAN; RoBERTS, 2012), que atesta a infraestrutura da política sexual e cria importantes fronteiras entre a realização ou não do aborto seguro. Nesse sentido, a informação orientada para o uso seguro de medicamentos para realização do aborto como medida do risco para sua realização vem não somente enfrentando formas de repressão simbólicas, como também punitivas. Em setembro de 2019, a revista virtual AzMina divulgou uma reportagem na qual apresentou recomendações da Organização Mundial da Saúde para realização do aborto seguro por meio de medicamento, uma estratégia para enfrentar as consequências da clandestinidade do aborto e de "democratizar o acesso à informação e desmedicalizar um processo que não necessariamente tem que estar exclusivamente nas mãos do profissional de saúde" (JAIME; VALDIVIA, 2020, p. 21). Como forma de reação a essa reportagem, Damares Alves ofereceu uma denúncia ao Ministério Público, alegando que estariam fazendo "apologia ao crime”, incentivando

8 Sancionada por Dilma Rousseff, a lei prevê o "atendimento obrigatório e integral de pessoas em situação de violência”. 
a prática clandestina e incluindo "receitas de como praticar um aborto". Dentro dessa "mentalidade anticonceptiva" encontramos também o PL 3415/2019, apresentado por Filipe Barros (PSL/PR) e endossado pela relatoria de Chris Tonietto, no qual busca-se agravar a pena para quem "vende medicamento abortivo", sob a justificativa de "reduzir o número de abortos clandestinos que ocorrem no país, preservando o direito à vida”. Nesse sentido, enquanto a informação sobre o uso do medicamento para realização de um aborto seguro visa mitigar os efeitos da clandestinidade, para os deputados antidireitos a disponibilização e a propaganda de medicamentos abortivos agravam o quadro de realização de abortos clandestinos e violam a lei.

A deputada Chris Tonietto adquiriu notoriedade desde o período da campanha eleitoral de 2018, atuando no enfrentamento ao "ativismo judicial" e caracterizando o parlamento como o espaço onde a vontade do povo se concretiza. É importante observar que grande parte das proposições legislativas que versavam sobre o “ativismo judicial” em 2019 foram propostas por deputados do Partido Social Liberal (PSL), sendo 15 das 25 proposições apresentadas por Chris Tonietto. Um dos grandes motivos para o enfrentamento ao "ativismo judicial" decorre de ações propostas que visam assegurar para a mulher o direito à realização do aborto nas hipóteses de microcefalia/zika vírus. Em 2019 foram apresentadas sete proposições no sentido de contestar a ADI 5881, afirmando tratar de forma a "legalizar a prática da eugenia". Nesse sentido, para esse grupo antidireitos o "aborto preventivo" seria, na realidade, uma forma de aborto eugênico. Além de solicitar para Dias Toffoli o arquivamento da ADI, alegando que "o aborto fere, de forma claríssima, o código moral que todo homem [sic] traz inscrito em sua consciência e que pertence ao patrimônio comum de todos os povos, religiões e culturas" (ToniETTo, 2020), Chris Tonietto também apresentou juntos com outros deputados o Projeto de Lei 1945/2020, que visa aumentar a pena na hipótese de "aborto realizado em razão de microcefalia ou qualquer outra anomalia ou malformação do feto".

Muitas propostas legislativas que buscavam agravar a punição para o aborto e atribuir uma maior reprovabilidade para a sua realização, como é o caso da PL 1008/2019, da PL 1006/2019 e da PL 1007/2019, acabaram incitando o medo e a insegurança para sua realização, ainda que esta seja autorizada por lei. Nessa linha, temos a Lei 13.931/2019, aprovada pelo Congresso Nacional e que alterou a redação da Lei 10.778/2003, a qual prevê, além da notificação compulsória, a obrigatoriedade da comunicação externa à autoridade policial. A obrigatoriedade da notificação policial por parte do médico é uma forma não somente de intimidar a mulher quanto à realização do aborto nas hipóteses permitidas em lei, 
mas também uma forma de incitar o medo, tendo em vista a possibilidade de um procedimento de cuidado vir a ser convertido em procedimento de investigação. A PL 3290/2019, do Deputado Pedro Augusto Bezerra (PTB/CE), voltada para a criação de unidades habitacionais para mulheres em situação de violência, foi um projeto apensado à PL 4390/2012, proposta originalmente pelo Major Fábio (DEM/ $\mathrm{PB}$ ), este, por sua vez, apensado à PL 7072/2002, apresentada pelo ex-Senador Mauro Miranda Soares (PMDB/GO).

O que queremos ressaltar com isso é que um projeto, originariamente apresentado por parlamentares pertencentes a partidos de direita, tornou-se um problema para deputados que enxergam na criação dessas unidades habitacionais uma forma de sujeitar mulheres vítimas de violência a realizarem o aborto em lugares clandestinos. Nessa mesma direção, tivemos 20 proposições legislativas apresentadas em 2020 em reação aos Projetos de Lei 1444/2020 e 1552/2020, que estabelecem medidas emergenciais de proteção à mulher vítima de violência doméstica durante a pandemia do COVID-19, dentre elas o estabelecimento de Casas-Abrigo e Centros de Atendimento Integral e Multidisciplinares para Mulheres. As ações contra essas propostas de lei são uma espécie de Lei da Mordaça ${ }^{9}$ à brasileira, pois estabelecem estratégias políticas para fins de inviabilizar a autonomia das mulheres, obstaculizando qualquer tipo de política social de proteção e acolhimento a mulheres em situação de violência. Isso pode ser verificado de forma muito clara na Emenda de Plenário (EMP) 17 ao PL 1552/2020, dos deputados Eli Borges (SOLIDARI/TO), Paulo Pereira da Silva (SOLIDARI/SP), Carlos Chiodini (MDB/SC) e Jhonatan de Jesus (REPUBLIC/RR), que visa a proibir que os recursos necessários à aplicação do que propõe o Projeto de Lei ${ }^{\circ}{ }^{1}$.552, de 2020, para proteção a mulheres em situação de violência, sejam utilizados na aquisição ou manutenção de equipamentos, em serviços ou em quaisquer outros tipos de atividade que tenham relação, direta ou indiretamente, com o aborto provocado.

A EMP 7 ao PL 1444/2020, de autoria dos deputados Francisco Jr. (PSD/ GO) e Hugo Leal (PSD/RJ), questiona a criação de um canal exclusivo para atendimento psicológico a mulheres em situação de violência doméstica ou familiar, alegando tratar-se de dispositivo para criação de um "disque aborto", ou seja "um canal de comunicação que poderá orientar mulheres a realizar abortos, quando essas se sentirem violentadas sexualmente por seus companheiros”. Já a EMP 6 ao PL 1444/2020, dos mesmos proponentes, rejeita o estabelecimento de um

9 A Lei da Mordaça foi uma política instaurada em administrações republicanas nos Estados Unidos, a qual obrigava que as organizações beneficiárias dos fundos de cooperação internacional não trabalhassem ou não mencionassem o tema do aborto em nenhum de seus programas. 
"Programa de Aluguel Social Emergencial para mulheres de baixa renda em situação de violência doméstica ou familiar, que não obtenham vagas em casas-abrigo ou estabelecimentos congêneres", afirmando que "a concessão de aluguel social não deve ser ligada nem condicionada ao encaminhamento da mulher vítima de violência doméstica para uma rede articulada que possa facilitar ou induzir a realização de abortos provocados"(Brasil, CÂMARA Dos Deputados, 2020). Nesse sentido, o que observamos através das proposições legislativas apresentadas em 2019-2020, é que o grupo denominado “pró-vida" e antidireitos vem fazendo uso da infraestrutura da política sexual e do discurso da defesa da moral religiosa para extrapolar os limites de uma oposição às hipóteses na qual o aborto é permitido ou a impugnação aos protocolos de atenção e atendimento às mulheres, como apontam Monte e Vaggione (2019). O ativismo "pró-vida" e antidireitos, por meio dos argumentos aqui expostos, vem mobilizando um repertório jurídico-religioso para fins de obstaculizar todo e qualquer avanço em termos de direitos das mulheres e de políticas sociais voltadas para sua proteção.

\section{CONCLUSÃO}

Os últimos anos têm visibilizado uma cristalização de estratégias de fortalecimento do campo conservador, materializadas em uma multidimensionalidade de articulações. De um lado, transformações estruturais da religião levam minorias religiosas emergentes e ciosas por se afirmarem como sujeitos a se abrirem a contestações de dentro e de fora, seja em seus próprios termos, seja nos termos de seus adversários. De outro lado, a constituição de uma fronteira que separa o nós-conservador do eles-esquerdas-minorias-secularistas-etc. produz efeitos de gravitação entre vários atores, religiosos ou não; aproxima demandas em princípio distintas, tornando-as equivalentes entre si em relação ao que contestam; e apropria-se de formas de ação classicamente associadas a movimentos sociais radicais, de direita e esquerda. Tais estratégias têm incidido fortemente sobre a esfera do Estado - processos eleitorais, ocupação de posições no judiciário - e sobre a sociedade civil - associativismo, formação de quadros e mobilizações coletivas. Nesses termos, não há como distinguir com clareza o político e o religioso nesses processos.

A sub-representação de mulheres em frentes parlamentares estratégicas para os interesses das mulheres reflete não somente sua sub-representação no campo da política brasileira, como também uma certa "indisposição" de parlamentares de partidos da esquerda em se inserirem em frentes parlamentares no qual há um predomínio de ativistas antidireitos e "pró-vida". No entanto, o mesmo não 
se observa por parte dos parlamentares que integram frentes antidireitos e "pró-vida", que de forma concomitante integram frentes "progressistas" como forma de se posicionarem e exercerem oposição. A equivalência entre a posição que esses deputados ocupam nas diversas frentes parlamentares não é plena, podendo vir a indicar a existência de alianças e tensões que a princípio nos passam despercebidas.

A heterogeneidade interna da Frente Parlamentar Católica aponta para diversas formas de conceber o significante vida. Nos últimos dois anos observamos uma crescente no ativismo "pró-vida" no parlamento brasileiro: através da utilização de determinadas terminologias, fronteiras foram demarcadas entre, de um lado, o ativismo que milita por uma cultura de vida, e, de outro, não só o ativismo, mas também uma forma de governo anterior (associada às gestões petistas), que reforçam uma cultura de morte por meio de notas, normas técnicas e da abertura da esfera pública para o debate sobre o aborto. Apesar da maioria das propostas legislativas serem apresentadas por homens jovens, do sudeste e do sul do Brasil e com vínculo com a religião, podemos afirmar que existe um protagonismo de mulheres nesse ativismo antidireitos, sobretudo de mulheres que alinham o discurso religioso ao discurso jurídico como forma de legitimar seus argumentos.

Ao longo deste artigo, procuramos ilustrar várias dessas dinâmicas e contribuir para alguns debates já em curso, focalizando um tema que tem constituído um forte contencioso em torno de si, e que vem há muito mobilizando setores religiosos (embora hoje se trate de um espectro mais amplo) e reforçando uma reação política a conquistas sociais mesmo parciais que se deram desde meados dos anos 1990 e se intensificaram no período de 2003 a 2014, durante os governos petistas. O aborto, como índice do debate sobre gênero e sexualidade, nos permite captar vários desses aspectos da politização religiosa, ao mesmo tempo em que revela a complexa tessitura da ação coletiva e da ação política envolvendo a construção de identidades, agendas, formações discursivas e que, nos últimos anos, produziu crescente polarização indicativa de transformações hegemônicas ainda em curso.

\section{REFERÊNCIAS BIBLIOGRÁFICAS}

Aguilar, Raquel Gutiérrez. La lucha de las mujeres contra todas las violencias en México: reunir fragmentos para hallar sentido. In: GAGo, Verônica et al. 8M Constelación feminista: ¿Cuál es tu huelga? ¿Cuál es tu lucha?. Buenos Aires: Tinta Limón, 2018, p. $25-48$

Aнumada, Cristian Alejandro Venegas. El aborto en los países de la subregión andina: discursos, políticas y resistencias. Aposta: revista de ciencias sociales, n. 56, p. 1-45, 
2013. Disponível em: https://dialnet.unirioja.es/servlet/articulo?codigo $=4191191$. Acesso em: 13/05/2021.

Almeida, Ronaldo de. A onda quebrada - evangélicos e conservadorismo. Caderno Pagu, 50(e175001), 2017.

Biroli, Flávia. Reação conservadora, democracia e conhecimento.Revista deAntropologia, v. 61, n. 1, p. 83-94, 2018. Disponível em: https://www.revistas.usp. br/ra/article/ view/145515. Acesso em: 13/05/2021.

Biroli, Flávia; Vaggione, Juan Marco; Machado, Maria das Dores Campos. Gênero, neoconservadorismo e democracia: disputas e retrocessos na América Latina. 1. ed. São Paulo: Boitempo, 2020.

Biroli, Flávia; CAMinotti, Mariana. The conservative Backlash against gender in Latin America. Politics \& Gender, Volume 16, Special Issue 1: Special Symposium on Women's Parties. 2020.

Brasil, CÂmara dos Deputados. Emenda de Plenário a Projeto com Urgência. EMP 17 $\rightarrow$ PL 1552/2020. Proíbe a utilização de recursos na aquisição ou manutenção de equipamentos, em serviços ou em quaisquer outros tipos de atividade que tenham relação, direta ou indiretamente, com o aborto provocado. Disponível em: https:// www.camara.leg.br/proposicoesWeb/prop_mostrarintegra?codteor=1911566. Acesso em: 15/05/2021.

Brasil, Câmara dos Deputados. Emenda de Plenário a Projeto com Urgência. EMP $6 \rightarrow$ PL 1444/2020. Suprime o art. $5^{\circ} \mathrm{C}$ do Substitutivo ao PL $n^{\circ} 1.444 / 2020$, que estabelece medidas emergenciais de proteção à mulher vítima de violência doméstica durante a emergência de saúde pública decorrente da pandemia do coronavírus. Disponível em: https://www.camara.leg.br/proposicoesWeb/prop_mostrarintegra?codteor=19 11672\&filename $=\mathrm{EMP}+6+\% 3 \mathrm{D} \% 3 \mathrm{E}+\mathrm{PL}+1444 / 2020$. Acesso em: 15/05/2021.

Brasil, Câmara dos Deputados. Projeto de Decreto Legislativo de Sustação de Atos Normativos do Poder Executivo PDL $n^{0}$ 250/2020. Susta os efeitos da Nota Técnica ${ }^{0}$ 16/2020, do Ministério da Saúde, 2020a. Disponível emhttps://www.camara.leg.br/ proposicoesWeb/prop_mostrarintegra?codteor=1900608\&filename=PDL+250/2020. Acesso em: 17/05/2021.

Brasil, Câmara dos Deputados. Projeto de Decreto Legislativo de Sustação de Atos Normativos do Poder Executivo PDL no 271/2020. Susta a aplicação de Normas Técnicas expedidas pelo Ministério da Saúde, 2020b. Disponível em: https://www. camara.leg.br/proposicoesWeb/prop_mostrarintegra?codteor=1903363\&filename =PDL+271/2020. Acesso em: 17/05/2021.

Brasil, Câmara dos Deputados. Projeto de Lei PL no 2893/2019. Revoga o art. 128 do Decreto-Lei ${ }^{0}$ 2.848, de 7 de dezembro de 1940 (Código Penal). 2019 Disponível em: 
https://www.camara.leg.br/proposicoesWeb/prop_mostrarintegra?codteor=189759 8\&filename=PL+2893/2020. Acesso em: 17/05/2021.

Brasil, CÂmara dos Deputados. Projeto de Lei PL no 4233/2020. Altera as redações do parágrafo único do artigo 83 , dos artigos 213 , caput e $\S \S 1^{\circ}$ e $2^{\circ}$ e $217-A$, caput e $\S \S 3^{\circ}$ e $4^{\circ}$, todos do Decreto-lei $n^{0} 2.848$, de 7 de dezembro de 1940 e a do $\S 2^{\circ}$ do artigo $2^{\circ}$ da Lei no 8.072, de 25 de julho de 1990. 2020. Disponível em: https://www.camara.leg. br/proposicoesWeb/prop_mostrarintegra?codteor=1923160. Acesso em: 17/05/2021.

Brasil, CÂmara dos Deputados. Projeto de Lei PL nº 4149/2020. Institui a Semana Nacional do Nascituro. 2020. Disponível em: https://www.camara.leg.br/proposicoesWeb/ prop_mostrarintegra?codteor $=1781167 \&$ filename $=P L+4149 / 2019$. Acesso em: 17/05/2021.

Brasil, CÂmara dos Deputados. Projeto de Lei no 1977/2020. Altera e revoga dispositivos da Lei $n^{0} 12.845$, de $1^{0}$ de agosto de 2013, a fim de aprimorar sua redação. 2020. Disponível em: https://www.camara.leg.br/proposicoesWeb/prop_mostrarintegra? codteor $=1910172 \&$ filename $=P L+1977 / 2020$. Acesso em: 17/05/2021.

Brasil, Câmara dos Deputados. Projeto de Lei no 261/2019. Dispõe sobre a proibição do comércio, propaganda, distribuição e implantação pela Rede Pública de Saúde de Micro Abortivos e dá outras providências. 2019. Disponível em: https://www. camara.leg.br/proposicoesWeb/prop_mostrarintegra?codteor=1707073\&filenam e=PL+261/2019. Acesso em: 17/05/2021.

Brasil, CÂmara dos Deputados. Projeto de Lei $n^{0}$ 3415/2019. Inclui o $§ 3^{\circ}$ no art. 273 do Decreto-Lei $\mathrm{n}^{0}$ 2.848, de 7 de dezembro de 1940 - Código Penal, para agravar a pena para a venda de remédios abortivos e altera o inciso V, do art. 10, da Lei 6.437, de 20 de agosto de 1977 para incluir a aplicação de multa 10x maior que o mínimo legal para quem faz propaganda de medicamentos proibidos que provoquem aborto. 2019. Disponível em: https://www.camara.leg.br/proposicoesWeb/prop_mostrarintegra? codteor $=1762587 \&$ filename $=\mathrm{PL}+3415 / 2019$. Acesso em: 17/05/2021.

Brasil, CÂmara dos Deputados. Projeto de Lei no 1945/2020. Altera dispositivo do Decreto-Lei ${ }^{\circ}{ }^{2.848}$, de 7 de dezembro de 1940 (Código Penal), para fins de inclusão de causa de aumento de pena em caso de aborto realizado em razão de microcefalia ou qualquer outra anomalia ou malformação do feto. 2020. Disponível em: https:// www.camara.leg.br/proposicoesWeb/prop_mostrarintegra?codteor $=1883005 \&$ file name=PL+1945/2020. Acesso em: 12/ 05/2021.

Brasil, Câmara dos Deputados. Projeto de Lei no 1007/2019. Altera o Decreto-Lei no 2.848 , de 1940. 2019. Disponível em: https://www.camara.leg.br/proposicoesWeb/prop_ mostrarintegra?codteor $=1713143 \&$ filename $=P L+1007 / 2019$. Acesso em: 12/05/2021. 
Brasil, CÂmara dos Deputados. Projeto de Lei no ${ }^{0}$ 1006/2019. Altera o Decreto-Lei no 2.848 , de 1940. 2019. Disponível em: https://www.camara.leg.br/proposicoesWeb/prop_ mostrarintegra?codteor $=1713141 \&$ filename $=P L+1006 / 2019$. Acesso em: 12/05/2021.

Brasil, CÂmara dos Deputados. Projeto de Lei no ${ }^{0}$ 1008/2019. Altera o Decreto-Lei no ${ }^{0} .848$, de 1940. Disponível em: https://www.camara.leg.br/proposicoesWeb/prop_mostrar integra?codteor $=1713146 \&$ filename $=P L+1008 / 2019$. Acesso em: 12/05/2021.

Brasil, CÂmara dos Deputados. Projeto de Lei no ${ }^{0}$ 3290/2019. Altera a Lei no 11.340 , de 7 de agosto de 2006, para determinar a reserva de unidades habitacionais, em programas públicos ou subsidiados com recursos públicos, para atendimento de mulheres em situação de violência doméstica e familiar que possuam medidas protetivas de urgência, conforme os termos fixados pela Lei. Disponível em: https://www.camara. leg.br/proposicoesWeb/prop_mostrarintegra; jsessionid=nodeo3upytsgdomufıv1j 9avyfmkfo4854514. nodeo? codteor $=1759531 \&$ filename $=P L+3290 / 2019$. Acesso em: 15/05/2021.

Brasil, CÂmara dos Deputados. Projeto de Lei nº 4390/2012. Altera a Lei no 11.977, de 7 de julho de 2009, para prever tratamento prioritário às mulheres vítimas de violência doméstica e familiar. Disponível em: https://www.camara.leg.br/proposicoesWeb/ prop_mostrarintegra?codteor $=1022872 \&$ filename $=P L+4390 / 2012$. Acesso em: 14/05/2021.

Brasil, Câmara dos Deputados. Projeto de Lei no ${ }^{0}$ 1444/2020. Estabelece medidas emergenciais de proteção à mulher vítima de violência doméstica durante a emergência de saúde pública decorrente da pandemia do coronavírus. Disponível em: https://www.camara.leg.br/proposicoesWeb/prop_mostrarintegra?codteor=18 72652\&filename=PL+1444/2020. Acesso em: 14/05/2021.

Brasil, CÂmara dos Deputados. Projeto de Lei no ${ }^{0}$ 1552/2020. Dispõe sobre a proteção de mulheres em situação de violência durante a vigência do estado de calamidade pública, com efeitos até 31 de dezembro de 2020, ou enquanto durarem medidas de quarentena e restrições de atividades no contexto da pandemia do COVID-19 (Novo Coronavírus). Disponível em: https://www.camara.leg.br/proposicoesWeb/prop_mostrarintegra?c odteor $=1873271 \&$ filename=PL+1552/2020. Acesso em: 15/05/2021.

Brasil, Câmara dos Deputados. Requerimento de convocação de ministro no 1469/2020. Requer o comparecimento do Sr. Eduardo Pazuello, Ministro interino da Saúde, para prestar esclarecimentos acerca dos motivos da exoneração do corpo técnico da Coordenação de Saúde das Mulheres, da Coordenação-Geral de Ciclos da Vida e da revogação da nota técnica 16/2020 -COSMU/CGCIVI/DAPES/SAPS/MS, que visava garantir o acesso à saúde sexual e saúde reprodutiva em tempos da pandemia 
da COVID-19. 2020. Disponível em: https://www.camara.leg.br/proposicoesWeb/ prop_mostrarintegra?codteor=1901876. Acesso em: 17/05/2021.

Brasil, CÂmara dos Deputados. Requerimento de convocação de ministro no 600/2020.

Requer ao Ministro Interino da Saúde, Senhor Eduardo Pazuello, informações sobre as políticas de acesso à saúde sexual e saúde reprodutiva das mulheres no contexto da pandemia de Covid-19. 2020. Disponível em: https://www.camara.leg.br/ proposicoesWeb/prop_mostrarintegra?codteor=1902134\&filename=RIC+600/2020. Acesso em: 17/05/2021.

BRASIL. Lei $\mathrm{n}^{0}$ 12.845/2013. Dispõe sobre o atendimento obrigatório e integral de pessoas em situação de violência sexual. Diário Oficial da União 2013. Disponível em: http:// www.planalto.gov.br/ccivil_03/_ato2011-2014/2013/lei/l12845.htm. Acesso em: 17/05/2021.

BRASIL. Lei $\mathrm{n}^{0}$ 13.931/2019. Altera a Lei $\mathrm{n}^{0}$ 10.778, de 24 de novembro de 2003, para dispor sobre a notificação compulsória dos casos de suspeita de violência contra a mulher. Diário Oficial da União 2019. Disponível em: http://www.planalto.gov.br/ ccivil_03/_ato2019-2022/2019/lei/L13931.htm. Acesso em: 13/05/2021.

BRASIL. Lei no 10.778/2003. Estabelece a notificação compulsória, no território nacional, do caso de violência contra a mulher que for atendida em serviços de saúde públicos ou privados. Diário Oficial da União 2003. Disponível em: http://www.planalto.gov. br/ccivil_03/leis/2003/110.778.htm. Acesso em: 13/05/2021.

BRASIL. Ministério da Saúde. Secretaria de Atenção Primária à Saúde. Departamento de Ações Programáticas Estratégicas. Coordenação-Geral de Ciclos da Vida. Coordenação da Saúde da Mulher. Nota Técnica No 16/2020-COSMU/CGCIVI/DAPES/SAPS/MS. Acesso à saúde sexual e reprodutiva no contexto da pandemia da Covid-19.

BRASIL. Ministério da Saúde. Secretaria de Atenção à Saúde. Departamento de Ações Programáticas Estratégicas. Prevenção e tratamento dos agravos resultantes da violência sexual contra mulheres e adolescentes: norma técnica / Ministério da Saúde. Secretaria de Atenção à Saúde. Departamento de Ações Programáticas Estratégicas. Brasília : Ministério da Saúde, 1998.

BRASIL. Ministério da Saúde. Secretaria de Atenção à Saúde. Departamento de Ações Programáticas Estratégicas. Atenção humanizada ao abortamento: norma técnica / Ministério da Saúde, Secretaria de Atenção à Saúde, Área Técnica de Saúde da Mulher. Brasília : Ministério da Saúde, 2005.

BRasil. Supremo Tribunal Federal. Ação Direta de Inconstitucionalidade $n^{0}$ 5881/DF - Distrito Federal. Relator: Ministro Marco Aurélio. 2018. Disponível em: https:// portal.stf.jus.br/processos/detalhe.asp?incidente=5341622. Acesso em: 10/05/2021. 
Burity, Joanildo Albuquerque. A cena da religião pública: contingência, dispersão e dinâmica relacional.Novos estudos CEBRAP, n. 102, p. 89-105, 2015. Disponível em: https://www.scielo.br/pdf/nec/n102/1980-5403-nec-102-89.pdf. Acesso em: 13/05/2021.

Burity, Joanildo Albuquerque. Glocalização e mudança de identidade: missionários brasileiros pentecostais e carismáticos no Reino Unido. Religião e Sociedade, v. 38, n. 1, p. 14-35, 2018a. Disponível em: https://www.scielo.br/pdf/rs/v38n1/o10o8587-rs-38-1-0o014.pdf. Acesso em: 13/05/2021.

Burity, Joanildo Albuquerque. A onda conservadora na política brasileira traz o fundamentalismo ao poder?. In: Almeida, Ronaldo; Toniol, Rodrigo (Orgs.). Conservadorismos, fascismos e fundamentalismos: Análises conjunturais. Campinas: Ed. Unicamp, 2018b, p. 15-66.

Burity, Joanildo Albuquerque. Conservative Wave, Religion and the Secular State in Post-impeachment Brazil. International Journal of Latin American Religions, v. 2, n. 4, p. 83-107, 2020 .

Burity, Joanildo Albuquerque. ¿Ola conservadora y surgimiento de una nueva derecha cristiana brasileña? La coyuntura posimpeachment en Brasil. Ciencias Sociales $y$ Religión/Ciências Sociais e Religião, v. 22, e020015, 2020b. Disponível em: https:// econtents.bc.unicamp. br/inpec/index.php/csr/article/view/13754/9030. Acesso em: 13/05/2021.

CARrareto, Glacieri. A história da menina estuprada que engravidou e foi chamada de assassina. Agazeta, Espírito Santo, Agosto de 2020.

Casanova, José. Public Religions in The Modern World. Chicago: University of Chicago Press. 1994.

Casanova, José. Public religions revisited, In: De Vries, Hent. (Org.) Religion. Beyond a concept. Fordham: Fordham University Press, pp. 101-119, 2008.

Casanova, José. Religion challenging the myth of secular democracy. In: Christoffersen, Lisbet et al (orgs.). Religion in the 21st century: challenges and transformations. Farnham/Burlington: Ashgate, pp. 19-36, 2010.

Connoluy, William. Capitalism and Christianity, American style. Durham: Duke University Press, 2008.

Correa, Sônia. Aborto na cena política global: fios de história, desafios do momento. Revista de Salud Sexual y Reproductiva, n. 18, p. 1-15, 2004.

Deleuze, Giles; Guattari, Felix. Mil platôs: capitalismo e esquizofrenia, vol. 3. São Paulo: Editora 34, 1999. 
Dides, Claudia (Ed). Diálogos Sur-sur sobre religión, derechos y salud sexual y reproductiva: los casos de Argentina, Colombia, Chile y Perú. Santiago: UAHC: PROGÉNERO. 2004.

GAGo, Verónica. A potência feminista, ou o desejo de transformar tudo. São Paulo: Elefante, 2020.

Hтun, Mala. Sex and the State. Abortion, Divorce and the Family under Latin American Dictatorships and Democracies. Cambridge: Cambridge University Press, 2003.

LACERDA, Marina Basso. Neoconservadorismo: articulação pró-família, punitivista e neoliberal na Câmara dos Deputados. Tese (Doutorado em Ciência Política). Rio de Janeiro, Instituto de Estudos Sociais e Políticos, Universidade do Estado do Rio de Janeiro, 2018.

Machado, Maria das Dores Campos. Política e religião: a participação dos evangélicos nas eleições. Rio de Janeiro: Editora FGV, 2006.

Machado, Maria das Dores Campos. Discursos pentecostais em torno do aborto e da homossexualidade na sociedade brasileira. Cultura y Religión, v. 7, n. 2, p. 48-68, 2013.

MAchado, Maria das Dores Campos. O discurso cristão sobre a "ideologia de gênero". Revista Estudos Feministas, v. 26, n. 2, e47463, 2018. Disponível em: https://www. scielo.br/pdf/ref/v26n2/1806-9584-ref-26-02-e47463.pdf. Acesso em: 13/05/2021.

JAIME, Martín; VALDIVIA, Fátima (Eds.).Mujeres, aborto y religions en Latinoamérica Debates sobre política sexual, subjetividades y campo religioso. Lima: CMP Flora Tristán/UNMSM, 2020.

Mendonça, Ana. Advogada nomeada por Damares é contra aborto em caso de estupro. Estado de Minas, Minas Gerais, 31 de agosto de 2020.

Miguel, Luis Felipe; Biroli, Flávia; Mariano, Rayani. O direito ao aborto no debate legislativo brasileiro: a ofensiva conservadora na Câmara dos Deputados. Opinião Pública, v. 23, n. 1, p. 230-26o, 2017. Disponível em: https://www.scielo.br/pdf/op/ v23n1/1807-0191-op-23-1-0230.pdf. Acesso em: 13/05/2021.

Monte, María Eugenia; VAGgione, Juan Marco. Cortes irrumpidas. La judicialización conservadora del aborto en Argentina. Rupturas, v.9, n.1, p. 104-122, 2019. Disponível em: https://dialnet.unirioja.es/servlet/articulo?codigo=6671417. Acesso em: 13/05/2021.

MoRÁn FAÚndES, José Manuel. El desarrollo del activismo autodenominado "Pro-Vida" en Argentina, 1980-2014.Revista Mexicana de Sociología, v. 77, n. 3, p. 407-435, 2015. MoRÁn FAúndes, José Manuel. De vida o muerte. Patriarcado, heteronormatividad y el discurso de la vida del activismo "Pro-Vida" en la Argentina. Córdoba: Centro de Estudios Avanzados, 2017. 
Morán FaÚndes, José Manuel; Morgan, Lynn M. La vida no es una sola: los usos políticos de la "vida" en latinoamérica. Culturales, v.6, e326, 2018.

Morgan, Lynn M; RoberTs, Elizabeth F. S. Reproductive governance in Latin America. Anthropology \& Medicine, v. 19, n. 2, p. 241-254, 2012.

Musica, Jaris. Economía Política del Cuerpo. La reestructuración de los grupos conservadores y el biopoder. Lima: Centro de Promoción y Defensa de los Derechos Sexuales y Reproductivos, 2007.

ORo, Ari Pedro. A política da igreja universal e seus reflexos nos campos religiosos e políticos brasileiros. Trabalho apresentado no XXVI Encontro Anual da ANPOCS, Caxambu, 22 a 26 de outubro, 2002.

ORo, Ari Pedro. Religiões e eleições em Porto Alegre: um comparativo entre 2000 e 2004. Debates do NER, ano 5, n. 6, p. 9-34, 2004.

REzENDE, Lucas. Menina de 10 anos grávida tem aborto negado no ES e vai a outro Estado. UOL, Espírito Santo, 16 de agosto de 2020.

Rosado-Nunes, Maria José Fontelas. O aborto sob o olhar da religião: um objeto à procura de autor@s. Estud. sociol., 17 (32), 21-43, 2012.

RuBin, Gayle. El tráfico de mujeres: notas sobre la "economía política” del sexo. In: LAMAS, Marta (Org.). El género: La construcción cultural de la diferencia sexual. Universidad Nacional Autónoma de México, PUEG, México, 1996, p. 35-96.

Sevilla, Carolina M Neyra; Nicoli, Diego Quesado. El anticonceptivo oral de emergencia en el Perú: discursos y contradiscursos de una batalla judicial. In: JAIME, Martín; VALDIvia, Fátima. (Eds.) Mujeres, aborto y religiones en Latinoamérica: debates sobre política sexual, subjetividades y campo religioso, Lima: CMP Flora Tristán/ UNMSM, 2020.

SGRo, Candelaria; RabBia, Hugo; Iosa, Tomas. El Debate sobre el Matrimonio Igualitario en Córdoba. Actores, estrategias y discursos. Córdoba: Ferrerya Editor, 2011.

Stefanoni, Pablo. Biblia, buey y bala...recargados: Jair Bolsonaro, la ola conservadora en Brasil y América Latina. Nueva Sociedad n. 278, 2018.

Tonietro, Chris. O ministro Barroso e a cultura de morte. Gazeta do Povo. 2020. Disponível em: https://www.gazetadopovo.com.br/opiniao/artigos/o-ministrobarroso-e-a-cultura-da-morte/\#: :text=Pr\%C3\%A1tica\%2odas\%2omais\%20 contr\%C3\%A1rias\%20\%C3\%Ao, os\%2opovos\%2C\%2oreligi\%C3\%B5es\%20e\%20 culturas. Acesso em: 12/02/2021.

Vaggione, Juan Marco. Reactive Politicization and Religious Dissidence. The Political Mutations of the Religious in Social Theory and Practice. Social Theory and Practice, v. 31, n. 2, p. 233-255, 2005. 
VAGGIONE, Juan Marco. La sexualidad en el mundo post secular. El activismo religioso y los derechos sexuales y reproductivos. In: GerLero, M. Derecho a la sexualidad. Buenos Aires: Grinberg. 2009, p. 141-159.

VAGGIONE, Juan Marco. El activismo religioso conservador en Latinoamérica. Córdoba: CDD, 2010.

VAGGIONE, Juan Marco. Derechos sexuales y reproductivos. Repensando las dimensiones religiosas de la política. In: VVAA. Pensando los feminismos en Bolivia. La Paz: Conexión Fondo de Emancipación, 2012, p. 297-318.

VAGGIONE, Juan Marco. Laicidad y sexualidad. Cidade do México: UNAM, 2013.

VAGGIONE, Juan Marco. A restauração legal: o neoconservadorismo e o direito na América Latina. In: Biroli, Flávia; Vaggione, Juan Marco; Machado, Maria das Dores Campos. Gênero, neoconservadorismo e democracia: disputas e retrocessos na América Latina. Sâo Paulo: Boitempo, 2020.

VAGgione, Juan Marco; MujicA, Jaris. Algunos puntos de discusión en torno al activismo (religioso) conservador en América Latina. In: Vaggione, Juan Marco; MujicA, Jaris. Conservadurismo, religión y política. Perspectivas de investigación en América Latina (pp. 17-40). CIECS-CONICET-UNC. 2013.

VéLEz, Ana Cristina González. "La situación del aborto en Colombia: entre la ilegalidad y la realidade”. Cadernos de Saúde Pública, v. 21, n. 2, p. 624-628, 2005. Disponível em: https://www.scielo.br/pdf/csp/v21n2/30.pdf. Acesso em: 14/05/2021.

Recebido: 31/10/2020 | Aprovado: 12/03/2021 